\title{
Schleiermacher on justification: A resource for a Reformed theology of recognition?
}

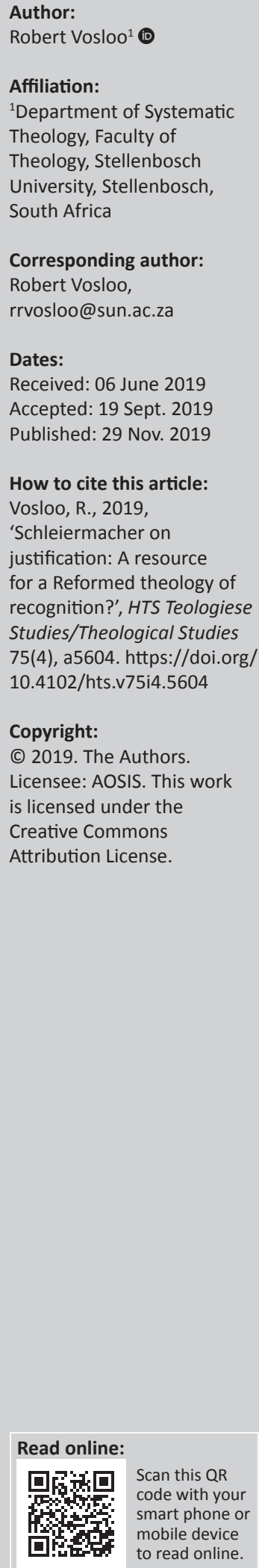

\begin{abstract}
Against the backdrop of the resistance against Schleiermacher's theology in Reformed theological circles in South Africa, this article poses the question as to whether Schleiermacher's theology can be brought into a constructive conversation with the views often associated with a Reformed understanding of God's grace. With this in mind, this article takes a closer look at Schleiermacher's exposition of the theme of justification in his Christian faith. This discussion of Schleiermacher's doctrine of justification is introduced by calling attention to some more recent attempts to re-read Schleiermacher in a way that at least complicates the view of him as standing antithetic towards the classical Reformed understanding of grace. Drawing on Schleiermacher's main thesis on justification, this article proposes that Schleiermacher's thought in this regard is historically and theologically significant for an attempt to bring the doctrine of justification in conversation with the notion of divine recognition.
\end{abstract}

Keywords: Schleiermacher; Justification; Recognition; Reformed Theology; Stellenbosch.

\section{Introduction}

During my theological studies in the late-1980s at the Faculty of Theology at Stellenbosch University, the name of Schleiermacher did not have a positive ring. Although he was respected by our teachers in Systematic theology for his brilliance and influence, Schleiermacher was first and foremost viewed as the father of the subjectivism of the 19th century, who reduced theology to the formulation of the pious emotional states of the human person (cf. Jonker 1981:86-89). At least in my mind, the impression was that the 'subjectivism' of Schleiermacher stood over against the classical Reformed emphasis on God's unconditional grace, as associated with the names of Augustine, Luther, Calvin and Barth. Maybe Barth's influential critique of Schleiermacher played a significant role in creating this negative image of Schleiermacher, even though Schleiermacher was born into a family of Reformed pastors and he himself was a Reformed pastor and theologian who identified with the Reformed tradition (Werner 2011:182), albeit deeply influenced by his encounter with the Moravian community. In his published 1923-1924 lectures on the theology of Schleiermacher at the University of Göttingen, Barth (1982) notably stated:

I have indeed no reason to conceal the fact that I view with mistrust both Schleiermacher and all that
Protestant theology essentially became under his influence, that in Christian matters I do not regard the
decision that was made in that intellectually and culturally significant age as a happy one, that the result
of my study of Schleiermacher thus far may be summed up by Goethe: 'Lo, his spirit calls to thee from the
cave: Be a man and do not follow me. (p. xvi)

Barth (1959:353) also concluded his discussion of Schleiermacher in his later book on Protestant theology in the 19th century, with specific reference to Schleiermacher's understanding of sin and grace, saying that, 'with Schleiermacher there can be no question of man's knowing that he is earnestly judged as a sinner, and equally earnestly ultimately pardoned' (1959:353). The result is for Barth that in the theology of Schleiermacher, 'man has alone remained the master ... to the extent that he alone is subject, and Christ has become his predicate' (1959:354).

Something of Barth's critique of Schleiermacher was communicated to us as students. We were, however, also made aware that Barth took Schleiermacher's theological project very seriously, and thoroughly engaged with his work. One can think in this regard of Barth (1982)'s statement about Schleiermacher: 
We have in him a classical figure. Those who have not noticed the brilliance of this figure or the charm that the exerted or still exerts; those who have not, I might almost say, succumbed to it, should not in this instance kick against the pricks. (p. xvi)

And, I can also remember that as a Master's student in theology at Stellenbosch, the professor in Systematic theology, Willie Jonker, prescribed for the exams Hendrikus Berkof's (1989) Two hundred years of theology: Report of a personal journey, of which the final paragraph of the chapter on Schleiermacher made a lasting impression:

As the first to think through so deeply the problems of modern theology, he is just as up-to-date and relevant for us as he was for his contemporaries. Perhaps we have to say more: more relevant. For in his day most theologians had as yet no inkling of what the problems were and could therefore lightheartedly shrug off Schleiermacher's answers. The bigger the blueprint, the longer the time before it takes effect. (p. 49)

Yet, the challenging question can still be posed as to how Schleiermacher's theology can be brought into a constructive conversation with the views often associated with a Reformed understanding of God's grace. With this question in mind, this article takes a closer look at Schleiermacher's exposition of the theme of justification in his Christian faith. This discussion of Schleiermacher's doctrine of justification is introduced by calling attention to some more recent attempts to re-read Schleiermacher in a way that at least complicates the view of him as standing antithetic towards the classical Reformed understanding of grace. Drawing on Schleiermacher's main thesis on justification, this article proposes - following the work of the Finnish Lutheran theologian Risto Saarinen - that Schleiermacher's thought in this regard is historically and theologically significant for an attempt to bring the doctrine of justification in conversation with the notion of divine recognition.

The concept of 'recognition' is receiving greater currency in moral and political discourse. As Fraser and Honneth (2003), two important theorists associated with recognition theory, write in the introduction to their polemical exchange, published under the title, Redistribution or Recognition?: A Philosophical-Political Exchange:

\footnotetext{
'Recognition' has become a keyword of our time. A venerable category in Hegelian philosophy, recently resuscitated by political theorists, this notion is proving central to efforts to conceptualize today's struggles over identity and difference. Whether the issue is indigenous land claims, or women's care work, homosexual marriage or Muslim headscarves, moral philosophers increasingly use the term 'recognition' to unpack the normative bases of political claims. They find that a category that conditions subjects' autonomy on intersubjective regard well captures the moral stakes of many contemporary conflicts. (p. 1)
}

The category of recognition has indeed found fertile ground in the discourses on multiculturalism and identity politics (see, for instance, Fukuyama 2018; Taylor 1994), also evoking some valuable conceptual clarification and critical reception (see McBride 2013; Oliver 2001; Ricoeur 2005). The purpose of this article is not, however, to give an overview of the discourse on recognition in social philosophy and cultural studies but is rather set against the background question regarding what resources one can draw upon en route to a constructive theology of recognition that links justification to (divine) recognition. Whereas much of the philosophical discourse on recognition see recognition as a modern concept stemming from Hegel, this study agrees with the remark by the Finnish Lutheran theologian Risto Saarinen in which he challenges how social theorists neglect religious and theological sources in their intellectual genealogy of recognition. Rather, he claims that the concept and conceptions of recognition are found in classical, medieval, and early modern religious sources' (2016:3). Saarinen's study then outlines an intellectual history of religious recognition from the New Testament to the present day, which he connects with philosophical approaches, indicating also in the process 'how philosophers owe a considerable historical and conceptual debt to the religious processes of recognition' (2016:4). In his account, Saarinen also includes an informative section on Schleiermacher. Drawing on Saarinen's discussion, this article proposes that while Schleiermacher's doctrine of justification has understandably been met with a critical reception in many Reformed theological circles, his emphasis that justification is broader than the mere justification of sinners and includes an account of adoption in which one is recognised as a child of God can serve a resource for a Reformed theology of divine recognition. In the process, I concur with the statement of Hector in his chapter on Friedrich Schleiermacher in The Cambridge Companion to Reformed Theology that Schleiermacher's lifework can indeed be seen as a contribution to Reformed theology (as opposed to say liberal or modern theology), an aspect that has not often been seriously entertained in many Reformed theological circles (2016:163-164).

\section{Contesting the reception of Schleiermacher on Justification and Grace}

Barth's reading of Schleiermacher referred to in the Introduction of this article, has not been uncontested. In his article entitled 'Schleiermacher on Justification: A Departure from the Reformation?' , Paul Nimmo, for instance, challenges, Karl Barth's negative verdict on Schleiermacher's doctrine of justification as radically discontinuous with the Reformation. Nimmo summarises and assesses Barth's critique with its three main points, namely, that there is in Schleiermacher no free act of God in justification but only a justification that takes place according to the law of nature; that the individual cooperates in justification as both God and human beings are seen as being active in the event of justification, and that justification takes place by the infusion of essential righteousness. Through his re-reading of Schleiermacher's doctrine of justification, Nimmo argues that Schleiermacher should be acquitted on these charges. Schleiermacher - in Nimmo's view - was not abandoning the soteriological 
concepts of the Reformation, but more likely was 'seeking to translate their meaning and significance into a more contemporary idiom for his own generation' (2013:71). Nimmo (2013:73) concludes his article by stating that it ultimately might be the case 'that Barth's doctrine of justification is in truth far more a departure from the theology of the Reformation than that of his erstwhile adversary Schleiermacher'.

Concerning the reception of Schleiermacher thought one can also refer to the charge that it lacks a theology of grace. In her 2008 article 'Schleiermacher's Treatise on Grace' Julia Lamm challenges this assumption (cf. Vander Schel 2013:110-120). She admits that the title of her article might be perplexing for many since Schleiermacher is not known for his treatment of grace, and much less for a treatise on grace. Yet she argues that within Christian Faith, or the Glaubenslehre as it is often referred to, is contained (Lamm 2008):

$[A]$ treatise on grace - that is to say, a delineated text that treats the subject of grace in a formal, methodical, and thorough manner - and furthermore, this treatise is of fundamental importance for Schleiermacher's dogmatic system. (p. 134)

She further argues that his treatment of grace is worthy of engagement since it is the first modern systematic treatment and that it also aims - while navigating the classical disputes at formulating a Protestant doctrine that respects the natural and historical sciences. For Lamm, Schleiermacher's treatise on grace is therefore fundamental to his mature theology. She writes in this regard (Lamm 2008):

[T] he Glaubenslehre could be said to be a Gnadenlehre, since everything in it is an explication of the Christian experience of having been redeemed by Christ, which is an experience of grace. (p. 135)

Lamm argues, furthermore, that Schleiermacher's treatise on grace, while recognisably Protestant, is not without resonances with certain traditionally Catholic emphases (2013:135-136). Lamm focuses mainly in her discussion of what she names Schleiermacher's treatise on grace on his discussion of conversion in par. 108 and sanctification in par. 112 of the Glaubenslehre. She does not focuses, however, specifically on Schleiermacher's discussion on justification in par. 109, and it is on this paragraph that I would like to emphasise this article.

\section{Schleiermacher on Justification}

In his explication of the contrasting features of religious self-consciousness in his Christian faith, Schleiermacher first discusses the consciousness of $\sin (\S 65-85)$ before turning to the consciousness of grace ( $\$ 85 \mathrm{ff}$.). The second aspect of the contrast (the consciousness of grace) is, in turn, divided into two sections, namely, the division regarding Christ (his person and work) and the division regarding how communion with the perfection and blessedness of the Redeemer is expressed in the individual soul. This selfconsciousness of one who is taken up into communion with Christ is then presented under the concepts of regeneration (Wiedergeburt) and sanctification.
With regard to regeneration, Schleiermacher (2016) opens with the leading doctrinal statement or Lehrsatz in $\S 107$ :

Being taken up into community of life with Christ, viewed as a human being's changed relationship to God, is that person's justification; viewed as a changed form of life, it is the person's conversion. (p. 686)

For Schleiermacher, these two aspects cannot be divorced from each other: conversion cannot be imagined without justification and justification, in turn, cannot be imagined without conversion. And given the fact that conversion and justification cannot be divorced from each other, they should be thought of as occurring simultaneously, with each being 'a reliable identifying mark of the other' (2016: 688).

Schleiermacher observes that given their reciprocity of conversion and justification, the order seems inconsequential. Yet, he starts, with conversion, stating (in §108) (Schleiermacher 2016):

In each individual, conversion viewed as the beginning of new life in communion with Christ, is manifested through repentance, which consists of the combining of contrition and change of heart, and through faith, which consists of a person's taking the perfection and blessedness of Christ into oneself. (p. 690)

According to Wynam, Schleiermacher (2016)'s position on conversion seeks the mean between two extremes:

Against the Pietists he denies that a precisely dateable conversion experience is necessary; against those who hold that conversion is unnecessary for those born in the church he puts forth arguments to show that everyone needs conversion. Thus his discussion of regeneration is both liberal and evangelical. (p. 144)

Concerning his second doctrinal proposition, regarding justification, Schleiermacher (2016) wrote:

God's justifying the person who is converting includes God's forgiveness of the person's sins and God's recognizing the person as a child of God. However, this turning about in the person's relationship to God truly occurs only insofar as the person has genuine faith in the Redeemer. (p. 710)

As was the case in the section on conversion, Schleiermacher provides quotations from Lutheran and Reformed confessional statements, such as the Augsburg Confession (1530), the Tetrapolitan Confession (1530), the Second Helvetic Confession (1566), the Gallican Confession (1559) and the Belgic Confession (1561). From the Belgic Confession, he (Schleiermacher 2015) quotes, for instance, section XXII and XXIII:

However, to speak more clearly, we do not mean that faith itself justifies us, for it is only an instrument with which we embrace Christ our righteousness ... We believe that our salvation consists in the remission of our sins for Jesus Christ's sake, and that therein our righteousness before God is implied. (p. 711)

Schleiermacher agrees with the emphasis in the Reformed confessions that the act of justification includes the remission of sins. Yet, he seeks a way of affirming the positive feature contained in the act of justification in a more sharply 
defined manner. Schleiermacher seeks to define the positive feature more directly by referring to the relation of 'filiation' (Kindschaft) or 'adoption' (Adoption). He faults the confessional documents for not paying enough attention to this, hence the need to turn to scriptural passages (such as Jn 1:12; Gl 3:26 and 4:5). One can mention in this regard, though, Brian Gerrish's remark that Schleiermacher could have found this emphasis in the Westminster Confession, in which the discussion of justification is immediately followed by a chapter on the grace of adoption. Gerrish also adds that Schleiermacher 'must have recognized that in seeing adoption as a cardinal metaphor he was in agreement with Calvin', albeit on the other hand that his conception of God 'inevitably set him at odds with the individualistic treatment of justification in Calvin and the entire dogmatic tradition' (2015:170). For Schleiermacher (Gerrish 2015:170), the moment of the person's justification is 'strictly the breaking through of God's eternal decree for humanity into the consciousness of the individual: the forgiveness of sin is the cessation of a guilty conscience'.

In his discussion of his leading doctrinal statement regarding justification, Schleiermacher (2016) further wrote that repentance (viewed as self-consciousness moved by one's consciousness of $\sin$ ):

[C]omes to rest in forgiveness, just as faith, made active by love from its very emergence onward, is in thought one's consciousness of being a child in relation to God, viewed as the same consciousness as that of being in community of life with Christ. (pp. 712-713)

Both the forgiveness of sin and being a child of God depend for Schleiermacher on the activity of Christ taken as a whole.

For Schleiermacher (2016:714), furthermore, it is not possible for Christ to live in us, unless the relationship between the Father and Christ the Son is being formed in us as well: 'Consequently, we participate in Christ's relationship of Son to the Father, which by the impression that Christ makes on us empowers us to be children of God'. Included in this form of empowerment is the guarantee of sanctification, 'for the right inherent in being children is directed to being reared to free cooperative activity within a household' (Schleiermacher 2016:714).

The two features of justification, that is, forgiveness of sin and community in Christ, cannot be separated. The divine adoption of human beings without forgiveness would be futile as it will beget fear and fear begets enslavement. On the other hand, no constancy in the relationship with God would be obtained without the reality of adoption or filiation. It is in their inseparability that these two features of justification (Schleiermacher 2016):

$[C]$ omprise the entire swing of human beings' relationship with God, which in combination with the putting off the old human being is called 'forgiveness of $\sin ^{\prime}$ and in combination with putting on the new human being is called 'adoption'. (p. 715)
But Schleiermacher is quick to point out that this way of presenting the matter would be open to misunderstanding if one holds the opinion that an individual would justify himor herself. According to Schleiermacher, this is not the case as everything hinges on the action of Christ and the divine decree. As DeVries and Gerrish comment on Schleiermacher's discussion, '... justification by faith occurs as the divine decree for humanity is appropriated by an individual who turns to Christ' (DeVries \& Gerrish 2005:202).

\section{Schleiermacher, justification and divine recognition}

Much more can be said about Schleiermacher's discussion on justification. The Reformed theologians Dawn DeVries and Gerrish argue for instance in their article, 'Providence and grace: Schleiermacher on justification and election' that what Schleiermacher thought about justification and election forms part of his understanding of God's providence. Hence, their claim: 'The operations of divine grace in justifying the sinner and gathering the church are determined by the mode of God's providential activity' (DeVries \& Gerrish 2005:190).

But for this article, I want to highlight how Schleiermacher uses the language of recognition in his discussion of justification. The doctrine of justification is not often related to the notion of recognition, although as Saarinen (2016:2) points out, 'the doctrine of justification of the sinners offers an intuitive counterpart to the psychology of recognition'. In his important and influential study Das Evangelium von der Rechtfertigung des Gottlosen als Zentrum des christlichen Glaubens (translated into English as Justification: The Heart of Faith), the German Lutheran theologian Eberhard Jüngel, as Saarinen notes, also affirms the analogy between justification and recognition. In this work Jüngel (2014) wrote:

The fact that people want to justify their conduct, their behavior, their past life and their claim to a future life is linked with the fact that people require recognition. It is essential for people to be recognized. Their personhood depends on it. As human beings we demand recognitions of ourselves. The wish for recognition has its source in the basic need for recognition. (p. 7)

As we live not only in relation to ourselves but also to our fellow human beings, we seek to justify ourselves to others or by responding to the request to give an account of ourselves, even sometimes in the context of a tribunal or a court. Against this background, Jüngel asks, whether one can justify somebody who is in the wrong, and declare the person free, without perverting the law. We should answer this question in the negative. Yet, Jüngel continues, the gospel of justification proclaims exactly that the person who is in the wrong and therefore deserves to be called sinner and Godless is justified by God, and thus finds acceptance or recognition (Anerkennung) with God. 'If I find acceptance (Anerkennung) with God', Jüngel writes, 'I am accepted irrevocably, once and for all. I have the right in the fullest meaning of the term to live and to live together with others' (2014:8). 
I recount Jüngel's discussion of justification here because he too explicitly relates justification to recognition (Anerkennung). For a theological account of recognition that draws on the doctrine of justification, one needs to give a fuller account than this article can provide here, but suffice to say that in such an account Schleiermacher can be a valuable conversation partner. In this regard, one can again recall Schleiermacher's statement: 'God's justifying the person who is converting includes God's forgiveness of the person's sins and God's recognizing the person as a child of God' (2016:710, italic my emphasis).

In his book Recognition and Religion, Saarinen makes three claims regarding this quotation and its link to recognition. He argues, firstly, that this quotation serves as 'the clearest early source of the explicit terminological expression of justification as recognition in the sense of a downward divine act'. Although there are some possible roots in Luther, the idea is here stated unequivocally. Secondly, and for Saarinen, more importantly, 'this quote shows how theology in the era starts to claim explicitly that humans are recognized by God'. Thirdly, Saarinen adds, 'Schleiermacher employs the old resources from Roman law that speak about filium agnoscere, recognizing a child' (2016:145).

For Saarinen, the innovative move on Schleiermacher's part concerns the relationship between justification, recognition and the doctrine of adoption. As already stated, Schleiermacher's discussion of justification contains both the forgiveness of sins and the recognition of being a child of God. As Saarinen (2016) puts it:

An adoption without forgiveness will only bring about servitude; the 'right of childhood' is a positive companion in which the person is educated as a member of the house. Both forgiveness and adoption are divine acts brought about by Christ. (p. 146)

The act of adoption can, therefore, be called a 'declaration of childhood', as what distinguishes Protestant theology is 'not only the forensic act of forgiveness but also the transformative act of adoption' (Saarinen 2016:146). The declarative and the effective aspects in the act of justification should therefore not be separated: 'The individual in this relationship', wrote Saarinen (2016):

$[B]$ ecomes a person because of the creative act of Christ, before that act he was only a 'part of the mass'. In this manner, the act of divine recognition is a performative statement that changes and transforms the relationship between God and human beings, making them persons. (p. 147)

Although Schleiermacher only uses the word 'recognition' in his leading doctrinal statement and not in his more elaborate exposition, the performative nature of his understanding of justifications indicates clearly for Saarinen what kind of recognition is at stake in Schleiermacher's discussion of justification. It is God that adopts people (here one can speak of 'downward recognition') and as such their consciousness is transformed into a new mode of being. According to Saarinen (2016:147), Schleiermacher 'may be the first thinker to interpret recognition as a divine salvific event that is expressed by the language of rights, combining several old and new aspects of recognition'.

Saarinen's discussion of Schleiermacher's doctrine of justification (and specifically Schleiermacher's reference to the divine recognition of the person as a child of God) points towards the historical and theological significance of Schleiermacher for an attempt to link the notion of (divine) recognition to justification. In this regard, it might be fruitful to compare Calvin's discussion of adoption within his discussion of justification (see Calvin, Inst. 3.14) with that of Schleiermacher. According to Saarinen's reading, Calvin does not make the connection with legal recognition, as does Schleiermacher. Therefore, his conclusion that 'the explicit idea of God "recognizing" individuals in the salvific event is not clearly stated before Schleiermacher' (Schleiermacher 2016:147-148). He also states that for Schleiermacher (2016:151) recognition is a mutual act 'in which the human upward recognition of a higher being has already been preceded by a divine act of affirmation'.

In the search of a (Reformed) theology of recognition, one can, therefore, argue, following Saarinen, that Schleiermacher's thought serves as a resource that affirms that upward recognition of the divine is preceded by, and grounded in, downward divine recognition in which God's justifying act recognises human beings as children of God. This reminds us that our recognition of God and others cannot be separated from the experience of 'being recognised'.

\section{Conclusion}

In his article on Schleiermacher for The Cambridge Companion to Reformed Theology, Hector (2016:177) writes that Schleiermacher's theology 'may provide helpful, distinctively Reformed resources for those who would carry on this theological tradition today'. He specifically mentions in this regard the fact how Schleiermacher portrays nature as a single, organic whole, and that this is an expression of its absolute dependence on God, does not require one to see a stark opposition between a theological and a naturalscientific view. For those who are interested in integrating faith with a naturalistic worldview, Hector (2016:178) continues, 'it may be good news that Schleiermacher belongs to their tradition'. To this one can add, in line with the argument of this article, that it may also be good news for those interested in developing a more elaborate theology of recognition.

The limitations of Schleiermacher's theology, and specifically his understanding of justification and election, for a theology of recognition, require a fuller discussion than I can provide here. This article's focus was merely to point to the fact that this kind of inquiry holds much promise for such an endeavour, given, among other aspects, Schleiermacher's broadening of the concept of justification to include an understanding of what Saarinen has termed 'downward recognition'. 
In the Introduction of this article, I also mentioned that as graduate students the image of Schleiermacher presented to us was rather negative in terms of the overall Reformed trajectory of our theological education. In reading Schleiermacher's discussion of justification with his focus on adoption and filiation (Kindschaft), I was also reminded of the similarities of these ideas with the title and content of a book by one of the first professors at the Theological Seminary at Stellenbosch, Professor Hofmeyr. The title of this book from 1896 is Niet knecht, maar Kind (Not Slave but Child). This book has as its motto Galatians 4:7: Gij zijt niet meer een dienstknecht, maar een zoon (You are no longer a slave, but a son). The book is divided into three sections. The first section is on 'Child' and deals with the idea that you are a child not a slave and specifically a child in Christ. Hofmeyr writes extensively about what he calls the spirit of being a child (kindskap). The second part focusses more specifically on what it means to be not a slave but a child, with specific reference to the notions of law and freedom. In the third part, Hofmeyr offers what he calls knectelikjke en kinderlijke gedachten (ideas about being a slave and a child), but one can argue that this part it is in many ways a condensed systematic theology, in which he speaks of God as Father, including God's love and wrath; about Jesus Christ, Scripture, sin and forgiveness. He also, in speaking of the order of salvation, follows an order similar to Schleiermacher, by first speaking of conversion and forgiveness, and then about justification.

May be one can, therefore, say that notwithstanding the negative view of Schleiermacher during the 20th century at Stellenbosch, the spirit of Schleiermacher was not completely absent at the theological seminary in Stellenbosch during the 19th and early 20th centuries. Or maybe one can say that the sense of Schleiermacher as being closer to Calvin and the Reformed tradition was more closely felt than in later decades.

\section{Acknowledgements Competing interests}

The author declares that he has no financial or personal relationships which may have inappropriately influenced him in writing this article.

\section{Author's contributions}

R.V. is the sole author of this research article.

\section{Ethical considerations}

This article followed all ethical standards for a research without direct contact with human or animal subjects.

\section{Funding information}

This research received no specific grant from any funding agency in the public, commercial, or not-for-profit sectors.

\section{Data availability statement}

Data sharing is not applicable to this article as no new data were created or analysed in this study.

\section{Disclaimer}

The views and opinions expressed in this article are those of the author and do not necessarily reflect the official policy or position of any affiliated agency of the author.

\section{References}

Barth, K., 1959, From Rousseau to Ritschl, SCM Press, London.

Barth, K., 1982, The Theology of Schleiermacher, edited by D. Ritschl and translated by G.W. Bromiley, p. xvi, Eerdmans, Grand Rapids, MI.

Berkhof, H., 1985, 200 Jahre Theologie: Ein Reisebericht, Neukirchener Verlag, Neukirchen-Vluyn.

Berkhof, H., 1989, Two hundred years of theology: Report of a personal journey, Eerdmans, Grand Rapids, MI.

DeVries, D.A. \& Gerrish, B.A., 2005, 'Providence and Grace: Schleiermacher on justification and election', in J. Mariña (ed.), The Cambridge Companion to Friedrich Schleiermacher, pp. 189-207, Cambridge University Press, Cambridge.

Fukuyama, F., 2018, Identity: The Demand for Dignity and the Politics of Resentment, Profile Books, London.

Fraser, N. \& Honneth, A., 2003, Redistribution or recognition? A political-philosophical exchange, Verso, London.

Gerrish, B.A., 2015, The Christian faith: Dogmatics in outline, John Knox Press, Louisville, KY.

Hector, K.W., 2016, 'Friedrich Schleiermacher', in P.T. Nimmo \& D.A.S. Fergusson (eds.), The Cambridge Companion to Reformed Theology, pp. 163-178, Cambridge University Press, Cambridge.

Hofmeyr, N.J., 1896, Niet knecht maar kind, Jacques Dusseau \& Co., Amsterdam.

Jonker, W.D., 1981, Die Gees van Christus, N.G. Kerk-boekhandel, Pretoria.

Jüngel, E., 2014, Justification: The Heart of the Matter, Bloomsbury T\&T Clark, London.

Lamm, J.A., 2008, 'Schleiermacher's Treatise on Grace', Harvard Theological Review $101 / 2,133-168$

McBride, C., 2013, Recognition, Polity Press, Cambridge.

Nimmo, P.T., 2013. Schleiermacher on Justification: A Departure From the Reformation?, Scottish Journal of Theology 66(1), 50-73.

Oliver, K., 2001, Witnessing: Beyond recognition, University of Minnesota Press, Minneapolis, MN.

Ricoeur, P., 2005, The course of recognition, Harvard University Press, Cambridge, MA.

Saarinen, R., 2016, Religion and religion: A historical and systematic study, Oxford University Press, Oxford.

Schleiermacher, F., 2016, The Christian faith, vol. 2, A New Translation and Critical Edition, transl. T.N. Tice, C.L. Kelsey \& E. Lawler, in C.L. Kelsey \& T.N. Tice (eds.), Westminster John Knox Press, Louisville, KY.

Taylor, C., 1994, 'The politics of recognition', in A. Gutman (ed.), Multiculturalism, pp. 25-73, Princeton University Press, Princeton, NJ.

Vander Schel, K.M., 2013, Embedded grace: Christ, history, and the reign of God in Schleiermacher's Dogmatics, Fortress Press, Minneapolis, MN.

Werner, I., 2011, “'Die Reformation geht nocht fort!": Zum Theologie Friedrich Schleiermachers und Johannes Calvins', in M. Hofheinz, W. Lienemann \& M. Sallmann (eds.), Calvins Erbe: Beiträge zur Wirkingsgeschichte Johannes Calvins, pp. 182-203, Vandenhoeck \& Ruprecht, Göttingen. 